\title{
Mindent a szemnek! Egy dunántúli szálloda éttermi kínálatának vizsgálata a Kasavana - Smith modell szerint
}

\author{
Ivancsóné Horváth Zsuzsanna - Kőmíves Csaba - Nagy-Keglovich Júlia - Happ Éva \\ Széchenyi István Egyetem
}

\section{A TANULMÁNY CÉLJA}

A gasztronómia jelenleg reneszánszát éli, a különböző gasztronómiai trendek meghatározzák az éttermek étlap összeállítási gyakorlatát. A tanulmány célja, hogy vizsgálja egy dunántúli városban müködő étterem ételkínálatát az eladott adagszámok és az árrés dimenzióiban.

\section{ALKALMAZOTT MÓDSZERTAN}

A felelős vezetővel folytatott struktúrálatlan interjú után vizsgáltuk a kínálat szélességét, mélységét, majd az adatok idősoros elemzését végeztük el az étterem étlapjának választéka, valamint a forgalmi és költség adatai alapján. Az idősoros adatok feldolgozása során az elemzés figyelembe veszi a szezonalitást és összehasonlítja a vizsgált évek ugyanazon terminológiáját. A forgalmi és költségadatok felhasználásával Kasanava és Smith portfólió elemzési módszerével, az árrés és az eladott adagok száma alapján Menu engineering munkalap segítségével készítettük el az ábrázoláshoz szükséges adatsorokat.

\section{LEGFONTOSABB EREDMÉNYEK}

A kutatás a 2016-2019 közötti időszak értékesítési döntéseiröl mutat részletes képet. A vizsgálatok eredménye azt mutatja, hogy a választék csökkentésével, a különleges ételek kínálatával a gasztronómiai trendek teljesültek, azonban ez nem feltétlenül van összhangban az étterem elhelyezkedésével, célközönségének igényeivel. A modell felhasználásával először került sor a szezonalitás vizsgálatára, mely nem igazolta, hogy az étterem vendégei keresnék a szezonális ételeket.

\section{GYAKORLATI JAVASLATOK}

Egy jól megválasztott étlappal - ami az egyik legfontosabb marketingkommunikációs eszköz - az étterem képes arra, hogy befolyásolja a vendégek ételválasztásait. A színek, formák, az árak megfelelő használata mind hatnak a vendég tudatalattijára, amely a döntések nagy százalékáért felelős. Az étterem jellegét és vendégkörét jellemzően az étlapon található ételek határozzák meg. A vizsgált étterem esetében megoldás lehet a célcsoporthoz igazított árak mellett a marketingkommuniáció erősítése is. Az étterem kihasználva a nagy tér adta lehetőséget, a helyiség mobil megosztásával alkalmas lehet különböző célcsoportok kiszolgálására is.

Kulcsszavak: étlap, Kasavana-Smith, mátrix

DOI: 10.15170/MM.2020.54.03.07 


\section{BEVEZETÉS INTRODUCTION}

Az étlapelemzés kevésbé vizsgált terület a magyar tudományos élet palettáján. Sándor (2007) kutatásában a Dél-Dunántúl turisztikai régió tájjellegű ételeit vizsgálta ételföcsoportok szerint. Kőmíves (2018) Győr és környékének gasztronómia gyökereit vizsgálta empirikus kutatásában. Ivancsó Kömíves (2018) a Rábaköz és a Szigetköz étlapjait elemezte szintén a tájjellegü ételekre fókuszálva. A kínálat és a forgalom összefüggéseinek vizsgálatára azonban a szerzők nem találtak példát a hazai szakirodalomban.

Az étlap szerves része az étteremnek. A vendégek az étlap alapján véleményt formálnak az adott étteremről. Az étlap az érzékszervekre hat: a grafika és a papír minősége nagyon fontos tényezők a megítélés során, de idetartozik az is, hogy az egyes ételek hol és hogyan helyezkednek el az adott étlapon. Míg a külcsín a marketingeszközök közé tartozik, addig az ételek összeállitása és elhelyezése az étlapon a profitszerzést segíti elő. Természetesen már a tanulmány elején érdemes azt leszögezni, hogy a vendégek nagyarányú száma nem jelent egyet a profitmaximalizálással, hiszen a vendégek választása nem mindig a legjövedelmezőbb ételre esik. Éppen ezért nagy jelentőségü, hogy az étlap olyan ételeket tartalmazzon, melyek megfelelő hozamot generálnak, miközben értéket és elégedettséget biztosít a vendégeknek, azaz az étlap jelentősége az étterem jövedelmezősége és a vendégelégedettség oldalról megközelítve is nagy. Egy bővülő versenytársi helyzetben a megfelelő árazású és grafikájú étlap elengedhetetlen kelléke az étteremnek. A megfelelő ételek kiválasztása nem egyszerü feladat. A különböző étlapelemzési mátrixok használatával hatékonyabban lehet összeállítani az étlapot, hiszen feltérképezésre kerülnek velük, hogy melyek a nyereséget/veszteséget termelö ételek.

Ebben a tanulmányban bemutatásra kerülnek a szakirodalmi áttekintés során az egyes elemzési lehetőségek. A primer kutatás során pedig egy nyugat-dunántúli étterem étlapja kerül megvizsgálásra a Kasavana-Smith modell alapján.

\section{SZAKIRODALOMI ÁTTEKINTÉS LITERATURE OVERVIEW}

Az 1997. évi CLV. törvény a fogyasztóvédelemröl 14 § (3.4.5.) elö́rja, hogy „Az eladási árat, az egységárat, illetve a szolgáltatás diját egyértelmüen, könnyen azonosíthatóan és tisztán olvashatóan kell feltüntetni. Az eladási árat és az egységárat, illetve - határon átnyúló szolgáltatásnyújtás kivételével - a szolgáltatás diját Magyarország törvényes fizetőeszközében kifejezve, a fizetőeszköz nemét (forint) vagy annak rövidítését ( $\mathrm{Ft}$ ) megjelölve kell feltüntetni. A termék eladási áraként és egységáraként, illetve a szolgáltatás díjaként a fogyasztó által ténylegesen fizetendő, az általános forgalmi adót és egyéb kötelező terheket is tartalmazó árat kell feltüntetni”(https://net.jogtar.hu/jogszabaly?docid=99700155.tv). Az étlap a vendéglátó üzletben eladásra kínált árukat tartalmazza tételesen ${ }^{1}$, menynyiségi egységre vonatkoztatva (adag), Magyarország törvényes fizetőeszközében (forintban), általános forgalmi adóval feltüntetett bruttó fogyasztói árral. Az étlap fogalmi meghatározására a szakirodalomban számos definíció létezik. Borda és tsai $(1993,31)$ szerint ,az étlap az étterem tükörképe”, az ételválaszték bemutatása az árak megjelölésével. Számot ad az üzlet színvonaláról, választékáról, az ott dolgozók szakmai tudásáról....". Dunszt és tsai $(2005,475)$ előbbi szerzők megfogalmazását a következővel egészíti ki: „Felhívja a vendég figyelmét és fogyasztásra ösztönöz,... étkezési kultúránk, üzletpolitikánk, szaktudásunk jó hírének terjesztője, az üzlet szakmai névjegye". Voleszák (2006, 68) értelmezésében ,az étlap a melegkonyhás üzletekben az ételválasztékot árakkal együtt bemutató árlap".

Az étlapok összetételének elemzésére alkalmas módszer a vertikális és horizontális vizsgálat, valamint a választék minősége. Az alábbi 1. számú táblázat az étlapelemzések különböző szempontjait szemlélteti.

Szigorú szakmai csoportosítás szerint (a fogyasztás sorrendjében; hideg előétel, leves, meleg előétel, halételek, szárnyasok, sertés, borjú, marha, vad, befejező fogások (sajtok, édességek, gyümölcsök). 


\section{1. táblázat: Az étlap elemzések összefoglaló táblázata \\ Table 1. Summary table of menu analyses}

\begin{tabular}{|c|c|c|c|c|c|c|}
\hline \multirow{2}{*}{$\begin{array}{l}\text { Modellek } \\
\text { Étlapelemzés - } \\
\text { MAM }\end{array}$} & \multirow{2}{*}{$\begin{array}{l}\text { Szerző(k) } \\
\text { Miller }\end{array}$} & \multirow{2}{*}{$\frac{\text { Évszám }}{1980}$} & \multicolumn{4}{|l|}{ Jellemzőik } \\
\hline & & & Győztesek & Mellékes II. & Mellékes III. & Vesztesek \\
\hline $\begin{array}{l}\text { Étlaptervezési } \\
\text { modell - MEM }\end{array}$ & $\begin{array}{l}\text { Kasavana- } \\
\text { Smith }\end{array}$ & 1982 & Sztárok & $\begin{array}{l}\text { Igavonók/ } \\
\text { Fejöstehenek }\end{array}$ & Kérdőjelek & $\begin{array}{l}\text { Döglött } \\
\text { kutyák }\end{array}$ \\
\hline Költségelemzés & Pavesic & 1983 & Tökéletesek & Állandók & Alvók & Problémások \\
\hline $\begin{array}{l}\text { A szervezeti } \\
\text { céloknak meg- } \\
\text { felelő (nettó } \\
\text { nyereségcél) (1) }\end{array}$ & $\begin{array}{l}\text { Hayes - } \\
\text { Huffman }\end{array}$ & 1985 & \multicolumn{4}{|c|}{ egyedi eredmény kimutatás az összes ételre } \\
\hline $\begin{array}{l}\text { Népszerüségi } \\
\text { index }\end{array}$ & Kotschevar & 1994 & \multicolumn{4}{|c|}{$\begin{array}{l}\text { viszonyszám; az adott étel az összes eladott adagszám } \\
\text { hányadosa }\end{array}$} \\
\hline $\begin{array}{l}\text { Mennyiség, } \\
\text { költség }\end{array}$ & $\begin{array}{l}\text { LeBruto, } \\
\text { Quain és } \\
\text { Ashley }\end{array}$ & 1995 & \multicolumn{4}{|c|}{$\begin{array}{l}8 \text { kimenet; magas költség igáslovak, magas költség } \\
\text { csillagok, alacsony költség traktor, alacsony költség fénylö } \\
\text { csillag, magas költség döglött kutya, magas költség } \\
\text { kérdőjel, alacsony költség kérdőjel }\end{array}$} \\
\hline $\begin{array}{l}2 \text { dimenziós } \\
\text { mátrix }\end{array}$ & $\begin{array}{l}\text { Cohen, } \\
\text { Mesika, és } \\
\text { Schwartz (2) }\end{array}$ & 1998 & \multicolumn{4}{|c|}{$\begin{array}{l}\text { figyelembe veszi az élelmiszerköltségeket, az árakat, } \\
\text { a munkaerőköltségeket, a népszerüséget, az étlap haté- } \\
\text { konyságának értékeléséhez. Mivel egy étteremben több } \\
\text { feladat zajlik egyszerre, ahol több különbözö étel készül } \\
\text { egyszerre, a pontos munkaerököltségek felosztása össze- } \\
\text { tetté válik. }\end{array}$} \\
\hline \multirow[t]{2}{*}{$\begin{array}{l}\text { Rövidtáv- } \\
\text { hosszú táv }\end{array}$} & $\begin{array}{l}\text { Bayou - } \\
\text { Bennett }\end{array}$ & 1992 & \multicolumn{4}{|c|}{ reggeli, ebéd, vacsora föcsoportok elemzése } \\
\hline & Horton & 2001 & \multicolumn{4}{|c|}{$\begin{array}{l}\text { MEM újra gondolva } 2 \text { síkon; munkaerö költséggel, illetve } \\
\text { anélkül }\end{array}$} \\
\hline $\begin{array}{l}\text { Alternatív } \\
\text { lehetőségek }\end{array}$ & & & \multicolumn{4}{|c|}{$\begin{array}{l}\text { DEA-Data Envelopment Analysis; többváltozós elemzés } \\
\text { a nyereségesség vizsgálatára (népszerüség, elégedettség, } \\
\text { marketing) }\end{array}$} \\
\hline $\begin{array}{l}\text { Tevékenység- } \\
\text { alapú költség- } \\
\text { számítás }\end{array}$ & $\begin{array}{l}\text { Raab és } \\
\text { Mayer }\end{array}$ & 2007 & \multicolumn{4}{|c|}{$\begin{array}{l}\mathrm{ABC}(=\text { activity-based costing), amely az összes müködési } \\
\text { költséget a menüelemekhez köti }\end{array}$} \\
\hline
\end{tabular}

Megjegyzés: (1) Minden menüponthoz nyereség- és veszteségkimutatást készit. Értékesitett mennyiség (bekerülési érték+ fix költségek + változó költségek) = a menüelem nettó nyeresége. (2) Az ideális tartományt 8-10-ig, az elfogadható tartományt 4-töl 8-ig terjedö tartományban határozták meg, az elfogadhatatlan tartományt 0 és 4 között. Vizsgálatuk nem adott magyarázatot arra, hogy a munkaerököltségeket miként mérték vagy számitották ki.

Forrás: saját szerkesztés 
Az első modellt Miller hozta létre 1980-ban. Ez az ún. MAM (Menu Analysis Model), magyarul étlapelemzési modell, melynek segítségével definiálhatóvá válnak azok az ételek, melyek egyrészt népszerüek, másrészt alacsony bekerülési rátájuk van. Miller egy négy negyedből álló mátrixot hozott létre, ahol a mennyiség és az átlagos ételkészítési költségek százalékos megoszlása a két tényező. A négy negyed elnevezései: Győztesek: magas népszerüségi és alacsony bekerülési rátával, Mellékes II: magas népszerüségi és magas bekerülési rátával, Mellékes III: alacsony népszerüségi és bekerülési rátával, Vesztesek alacsony népszerüségi és magas bekerülési rátával. Miller szerint, amennyiben $60 \%$-a az ételeknek a Győztesek és a Mellékes III kategóriában vannak, az már megfelelő az étterem számára.

Kasavana és Smith 1982-ben módosították a Miller modellt és az elóállítási költségek helyett az árrést vették alapul. A Kasavana-Smith (1982) modell alapjául a BCG-mátrix szolgált. A modell egyetlen hátránya az, hogy az árrést egyértelműen nyereségként könyveli el, pedig az árrés a költségekre és a haszonra nyújt fedezetet. A MEM (Menu Engineering Modell), azaz az étlaptervezési modell egyik legnagyobb korlátja, hogy előnyben részesíti a magasabb árú ételeket, amelyek viszont csökkentik a keresletet és a jövedelmezőséget. A mátrixban a „sztárok” negyedbe eső ételek azok, amelyek a legmagasabb árréssel és legnagyobb eladási számmal rendelkeznek. A „fejőstehenek” közé azok az ételek tartoznak, melyek magas eladási számmal és alacsony árréssel rendelkeznek. A „kérdőjelek” közé magas árrésủ és alacsony eladási számú ételek kerülnek. A „döglött kutyák” között alacsony árrésủ és alacsony eladási számú ételek szerepelnek.

1983-ban Pavesic tovább fejlesztette a fenti modelleket és megalkotta a CMAM (Cost Margin Analysis Model) modellt, mely a költségelemzésre helyezi a hangsúlyt. Az árrést és az étel elöállítás költségét veszi alapul. Ebben a modellben a „tökéletesek" az alacsony elöállítási költségű és magas jövedelmezőségủ ételek, az ,állandók” magas előállítási költségü és magas jövedelmezőségủ ételek, az „alvók” alacsony eloóllítási költségủ és alacsony jövedelmezőségű ételek és a „problémások” magas előállítási költségủ és alacsony jövedelmezöségú ételek. A három modell legnagyobb hibája Taylor és Brown (2007) szerint, hogy nem veszik figyelembe az egyéb költségeket, legföképpen a munkaerő költségeit.

Hayes és Huffman (1985) modellje az egyes ételek eredménykimutatására fókuszál a fix és változó költségek kiszámolásával. Véleményük szerint csak az az étel maradhat az étlapon, amelyik eredménykimutatása megfelel az előirányozott pénzügyi céloknak.

A LeBruto et al. (1995) féle modell a menütervezési modell tovább fejlesztett variációja, melyben a változó munkaerő költség alapján a 4 negyedet további 4 részre bontották, melyek mindegyikébenmagasésalacsonymunkaerőigényüételek szerepelnek.

Cohen et al. (1998) a kétdimenziós modellek korlátainak megoldásaként egy multidimenziós megközelítést adtak. Így az elemzésbe bekerültek az élelmiszer beszerzési költségek, az árak, a munkaerő költségek, a népszerüség és az árrés is. Ők egy 0-10 közötti skálán értékelték az ételeket, ahol a 8-10 közé eső ételek az ideálisak, a 4-8 közöttiek elfogadhatók és a 4 alatti ételek elfogadhatatlanok. Taylor és Brown (2007) szerint a legnagyobb hibája a modellnek, hogy egyrészt nem határozták meg, hogyan kerüljenek kiszámításra a változó költségek, beleértve a munkaerőköltséget, másrészröl nem vették figyelembe a termelés egyéb tényezöit.

Bayou és Bennett (1992) szerint az elemzésekből hiányoznak a következő elemzési körök: ételcsoportok szerinti elemzések, az étkezési idő (reggeli, ebéd vagy vacsora) valamint a rövid és hosszútávú jövedelmezősége az adott ételnek. A modelljükben (PAM) - jövedelmezőségi elemzési modell - meghatároztak általános költségeket, melybe pl. a hirdetési költségeket is beleértettek illetve véleményük szerint nagyon fontos a megfelelö költségfelosztás.

Horton (2001) a MEM modellt gondolta újra úgy, hogy a gyakorlatban ugyanazt az éttermi menüsort elemezte egyszer a munkaerő-költségekkel számolva, majd a munkaerő-költségek nélkül is. Kutatásai eredményeként elmondható, hogy a munkaerőköltség jelentős és érdemes vele kalkulálni, hogy megfelelő eredményeket kaphassunk.

Alternatív lehetőségként többváltozós elemzéseket is lehet alkalmazni a nyereségesség vizsgálatára (Taylor \& Brown 2007).

\section{A KUTATÁS MÓDSZERTANA RESEARCH METHODOLOGY}

Munkánkban egy nyugat-dunántúli étterem étlapját, kínálatát elemeztük több szempontból. A vizsgálat elött struktúrálatlan interjút folytattunk a felelős vezetővel, ami jó alapot szolgáltatott az étterem megismerésére és az elemzések megtervezésére. Vizsgáltuk a kínálat szélességét, mélységét, majd az adatok idősoros elemzését végeztük el az étte- 
rem étlapjának választéka, valamint a forgalmi és költség adatai alapján. Vizsgáltuk az étlap változását szezonalitás szerint, gondolva itt az alapanyagok változására, és időpont szerint, figyelembe véve különleges alkalmakat, ünnepeket.

Végül a 2016. januártól 2019. decemberig tartó időszakra megkapott forgalmi és költségadatok felhasználásával elsőként Kasanava és Smith portfólió elemzési módszerét választottuk, mint a leggyakrabban alkalmazott elemzési módszert, mivel jelenleg a felelős vezető által rendelkezésre bocsátott adatok nem tették lehetővé, hogy a költségnemeket az (anyagköltségek) elábé kivételével részletezve vizsgáljuk, márpedig más modellek használatához erre szükség lett volna Az árrés és az eladott adagok száma alapján Menu engineering munkalap segítségével készítettük el az ábrázoláshoz szükséges adatsorokat.

- A vizsgálat során a következő kutatási kérdéseket szerettük volna megválaszolni:

- $\quad$ Az étlap összeállítása mennyire felel meg a fogyasztói igényeknek?

- Van-e összefüggés az ételválasztás és a szezonalitás között?

- Van-e összefüggés az ételválasztás és az árak között?

- $\quad$ Mennyire felel meg az étlap az étterem színvonalának?

$\mathrm{Az}$ eredmények fényében javaslatokat fogalmaztunk meg az étterem étlapjának jövőbeni kialakítására.

Kutatásunk korlátai közt fontos megemlíteni, hogy a módszer maga csak az eladott áru beszerzési értékét és az árrést vizsgálja. Az árrés pedig különböző arányban tartalmazza a költségeket és az eredményt, amiröl így nincs teljes képünk. Fontos megemlíteni, hogy a modell nem foglalkozik a vendéglátásban nagy jelentőséggel bíró munkabér költségekkel, de a modellalkotók szerint ennek az az oka, hogy a munkabérek felosztása az egyes ételek között nagyon bonyolult lenne. Meg kell még említeni azt, hogy a modell sajátossága, hogy a számítási metódusok miatt kölcsönös függőség van az étlapon szereplö ételek között, emiatt mindig valamennyi mezőbe fognak kerülni ételek.

\section{A KUTATÁs TÁRgYÁNAK BEMUTATÁSA PRESENTATION OF THE RESEARCH SUBJECT}

A vizsgált étterem egy nyugat-dunántúli étterem, mely belváros közeli, de nem frekventált helyen található. Az étterem 100 féröhellyel rendelkezik, fó profilja a rendezvényszervezés, de de emellett nagy hangsúlyt fektetnek az a'la carte vendégek kiszolgálására is. Az étlap formailag letisztult, az étterem hangulatát, stílusát tükrözi, a színek az étterem arculatához igazodnak.

A választék számszerüleg a jelenlegi trendekhez igazodva szúk, de a pozícionálásnak megfelel. Az étlap szerkesztése nem követi az aktuális trendeket, mely szerint a korábbi években megszokott gyakorlattól eltérően a vendéglátó üzletekben az étlapon szereplő ételek (például bélszín Budapest módra) módozat szerinti feltüntetését kerülni kell. Helyette utalni kell az étel elkészítésének konyhatechnológiájára (tüzdelt, grillezett, sousvide, vaslapon sült), a hús fajtájára (fogas, borjú, vadkacsa) és az étel jellegét adó anyagokra (pörkölt alap, libamájas, zöldborsós ragu, rizs talapzaton). A fogyasztó viszonylag kevés étel közül kell, hogy megtalálja a kedvére valót. Az étlap mindösszesen három előételt, három levest, tíz fóételt, egy savanyúságot és négy desszertet tartalmaz.

$\mathrm{Az}$ étlapra felkerült ételekben is a különlegességet sugallják, bár a levesek között a „Rókagomba krémleves füstölt marhanyelvvel" mellett a „Gulyásleves lábszárból” és az 'Újházy tyúkhúsleves" kapott helyet.

Árazás tekintetében a fóételek árai 2990 Ft és 5990 Ft között vannak. Az étterem a pszichológiai árképzést alkalmazza, minden ár kilencvenre végződik. Az árakhoz még $10 \%$ felszolgálási díjat számítanak fel.

\section{AZ ÉRTÉKESÍTÉS IDŐSOROS ELEMZÉSE TIME SERIES ANALYSIS OF SALES}

A felelős vezetőtől megkapott adatok segítségével elemeztük az értékesítést 2016. január 1. és 2019. december 31. között. Először az értékesítés főbb mutatóit határoztuk meg. Az értékesítés nettó árbevétele, 2016 óta gyakorlatilag stagnál, sőt az utolsó két évben némiként csökkent is. Az ételek száma az étlapon 2016 és 2018 között 49 és 64 között volt. A 2019-es évnek új koncepcióval indult neki az étterem és a korábbi kínálatot leharmadolta. Az eladott adagok számának vizsgálata azt mutatta, hogy az étterem 2017-es évéhez tartozott a legmagasabb eladott adagszám, amikor közel 50 foétel kapott helyet az étlapon, hasonlóan a 2016-hoz. 2018-ban mélyebb volt a kínálat, azonban az értékesítés drasztikusan csökkent, hasonlóan 2019-hez, mikor egy sokkal szűkebb kínálat mellett döntöttek. 
Az árrés és az elábé vizsgálatánál azt látjuk, hogy az arány egyre inkább a magasabb árrés irányába tolódott, ezt a változást mutatja a haszonkulcs is (HK\%). Ennek az okaként a lefolytatott interjú alapján a korábbi nagyon alacsony árréstartalmat jelölték meg, amin mindenképp változtatni szerettek volna. (2. táblázat) Szükségszerü lenne egy fogyasztói megkérdezés is, hogy a problémákra fogyasztói oldalról is pontos választ kapjunk.

\section{2. táblázat: Az értékesítés főbb mutatói \\ Table 2. Key sales figures}

\begin{tabular}{|l|l|l|l|l|l|}
\hline Év & Ételek száma & Eladott adagok száma összesen & Árrés \% & Elábé \% & HK \% \\
\hline 2016 & 56 & 6833 & 55,8 & 44,2 & 122 \\
\hline 2017 & 49 & 6995 & 56 & 44 & 126 \\
\hline 2018 & 63 & 4970 & 63 & 37 & 175,7 \\
\hline 2019 & 21 & 4978 & 65 & 35 & 182 \\
\hline
\end{tabular}

Forrás: saját szerkesztés

Az értékesítés fő mutatóinak meghatározása után a fóételek értékesítéséhez kapcsolódó pénzügyi és értékesítési adatokat „Menu engineering munkalapok" segítségével rendeztük és értékeltük. Előbb az árrésadatokból minden évre meghatároztuk az átlagos árrésértéket és ehhez viszonyítva alacsony vagy magas árrés kategóriába soroltuk az egyes fóételeket, majd a menü kedveltségi index kiszámítása után az értékesítés mennyiségét az egyes fóételek esetén szintén alacsony és magas kategóriába soroltuk. A kapott értékeket Smith és Kasavana által használt módosított BCG mátrixba helyeztük el (3. táblázat).

3. táblázat: Az egyes mezők a Kasavana és Smith mátrixban Table 3. Individual fields in the Kasavana and Smith matrix

\begin{tabular}{|l|c|c|c|c|}
\hline & \multicolumn{2}{|c|}{ Értékesítés volumene } & \multicolumn{2}{c|}{ Árrés } \\
\hline & Alacsony & Magas & Alacsony & Magas \\
\hline Sztárok & & $\mathrm{X}$ & & $\mathrm{X}$ \\
\hline Kérdőjelek & $\mathrm{X}$ & & & $\mathrm{X}$ \\
\hline Fejöstehenek & & $\mathrm{X}$ & $\mathrm{X}$ & \\
\hline Döglött kutyák & $\mathrm{X}$ & & $\mathrm{X}$ & \\
\hline
\end{tabular}

Forrás: saját szerkesztés

A kapott ábrák sokat elárulnak az egyes évek értékesítési döntéseiröl. 2016-ban az év során az értékesített 56-féle fóétel többsége a sztárok és a fejös tehenek közé tartozott. Az ábra jól mutatja, hogy a legkedveltebb ételek a klasszikus, nem túl magas árkategóriába tartozó fóételek voltak, melyeknek az árrés tartalma meghaladta az átlagos szintet. A legnagyobb értékesítési volumennel a panírozott csirkerögök, a marhapörkölt, a grillkavalkád rendelkezett, ezek az ételek 17 további fóétellel együtt a magas árrés tartalmuknak köszön- hetően a „sztárok” közé kerültek. A serpenyős csirke, a pulykamell cordon bleu, a tejszínes spagetti, az óriás sertésszüz, hogy csak néhány ételt emeljünk ki a 16 klasszikus, kedvelt, de alacsony árrés tartalmú étel közül, a „fejős tehenek” közé kerültek. A magas áron értékesített - és ehhez kapcsolódóan magas árrés tartalommal is rendelkező - ételek többsége, összesen 15 étel a „kérdőjelek” közé került, mivel a kedveltségük ezeknek az ételeknek nem volt magas és az értékesített adagok nem érték el a magas kategóriát, pl. kemencés 
libamáj, lepényhal, bélszínsteak. 8 étel került a „döglött kutyák” közé, melyek alacsony árrés tartalommal rendelkeztek és a vendégek sem nagyon kedvelték/választották őket (1.ábra).

\section{1. ábra: A főételek értékesítési volumenének}

és árrésének ábrázolása Kasavana - Smith mátrixban (2016)

Figure 1. Representation of sales volume and margins of main courses in the Kasavana - Smith matrix (2016)

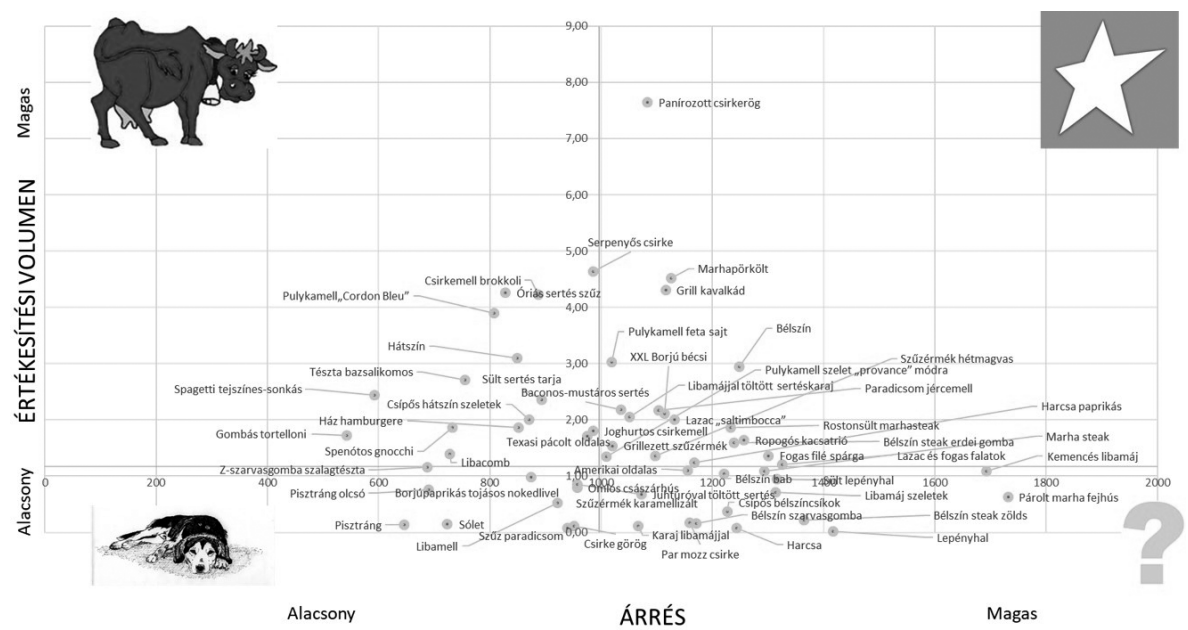

Megjegyzés: A mátrixban használt szimbólumok forrása: http://mediapedia.hu/bcg-matrix Forrás: saját szerkesztés

2017-ben a mátrixban jelentős átrendeződést találtunk (2. ábra). Ennek az átrendeződésnek az oka az értékesített adagszámok nagyobb mértékü szórása volt. Árrés tekintetében komoly változás az egyes ételek esetén nem figyelhető meg. Az egyes ételek elhelyezkedése a mezőkben annyiban változott, hogy az előző évhez képest a „döglött kutyák” között szereplö ételek száma több mint megduplázódott (18 étel) annak ellenére, hogy több étel is az előző éviek közül lekerült az étlapról. Már a második év elemzéséből is körvonalazódik a célcsoport - aki az éttermet látogatja -, valamint a megjelenö fogyasztói igények. Bár az étterem magasan pozícionálja saját magát, vélhetően elhelyezkedése és megítélése miatt mégsem azt a vendégkört vonzza be, melyet szeretne. A 2017-es fóételek „sztárjai” ismét a panírozott csirkerögök, emellett az XXL borjú bécsi, a baconos-mustáros sertés, a szüzérmék hétmagvas bundában, a marha pörkölt és a grillkavalkád vezeti a „sztárok” értékesítését a 12 ide kerülő étel közül. Az értékesítések alapján a legkedveltebb étel a „,fejős tehenek” között (11 étel) helyet kapó pulyka „cordon bleu”, a hátszín és a serpenyős csirke mellett. A halételek továbbra sem tartoznak a vezető ételek közé. Egyedül a lazac az, amely bár nem túl magas kedveltséggel, de mégis a „sztárok” között kapott helyet. A 2. ábra alapján megállapítható, hogy a kicsit különlegesebb ételek vagy a „kérdőjelek” (8 étel), vagy a „,döglött kutyák" között helyezkednek el. 


\section{2. ábra: A fóételek értékesítési volumenének és árrésének ábrázolása}

Kasavana - Smith mátrixban (2017)

Figure 2. Representation of sales volume and margins of main courses

in the Kasavana - Smith matrix (2017)

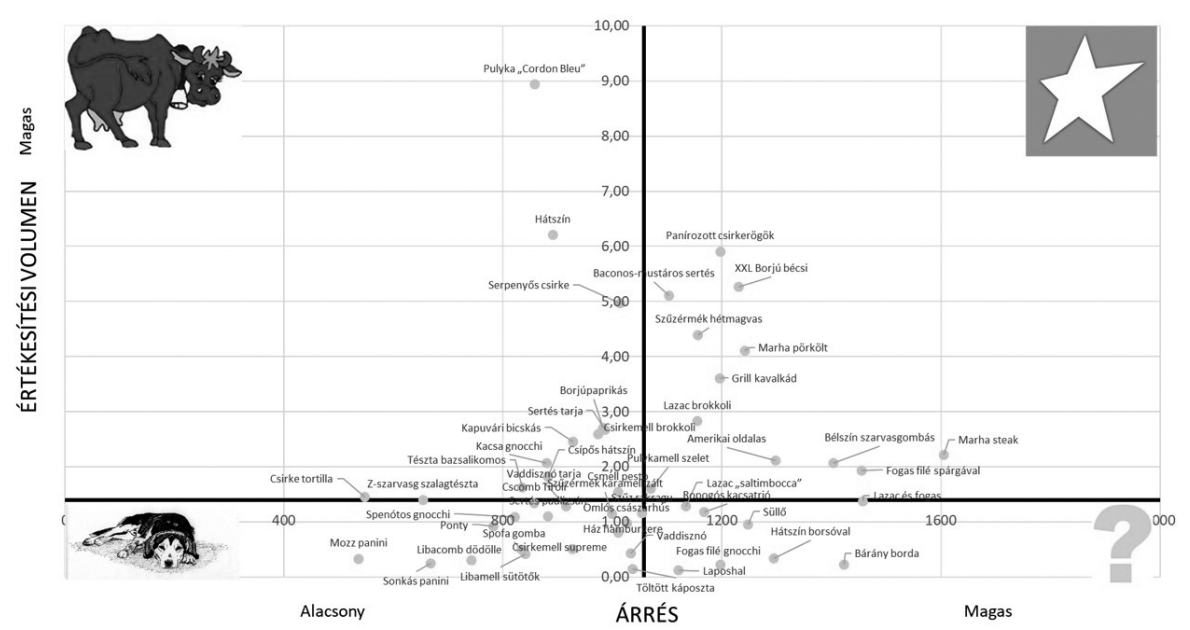

Megjegyzés: A mátrixban használt szimbólumok forrása: http://mediapedia.hu/bcg-matrix

Forrás: saját szerkesztés

A 2018-as év értékesítésének elemzése során a 2017-es adatokhoz nagymértékben hasonló adatokat kaptunk. Lényegi változást egyrészt az általánosságban jelentösen növekvő árrésszint hozott, melynek következtében a legjelentősebb növekedést produkáló ételek közül azokat, amelyek kedveltsége már korábban is magas volt a „sztárok” (20 étel) közé emelte. Ezen ételek többsége ismét a csirkemell különbözö variációit takarta, valamint a marhapörköltet. A halételek közül ismét a lazacfilé teljesített jól. Azok az ételek, melyek vagy elnevezésükben vagy technológiájukban kicsit különlegesebbek voltak, az elemzés során többnyire a „kérdőjelek” (10 étel) vagy a „döglött kutyák” (21 étel) közé kerültek. A „fejöstehenek” (12 étel) között a mázas kacsamellet kell kiemelni és a fogasfilét. E két étel volt a legnagyobb számban értékesített a „fejőstehenek” kategóriában és az árrésük is nagyon közel van az átlagos árrés szinthez.

A 2019-es év gyökeres változást hozott a kínálatban. A korábbi évek széles és mély kínálati struktúráját a fine dining éttermekre jellemző trendnek megfelelö, szük és sekély kínálat váltotta fel. A foételek választéka drasztikusan csökkent. A korábbi 49-63 fótel helyett pusztán 23 fótel kapott helyet az év során az étlapon. Az átlagos árrés szint tovább nőtt 2019-re. A koncepció azért érdekes, mert a korábbi évek bizonyították, hogy a vendégkör a hagyományos, relatív olcsó ételeket választotta elsősorban. Az igazán különleges, illetve drágább ételek értékesítése csak nagyon alacsony szinten valósult meg. A 23 étel közül 6 került a „sztárok” közé, 4 a „kérdőjelek” közé, 8 a „fejőstehenek” közé és a 7 a „döglött kutyák” közé.

A vendégek választását ezzel az étlappal sem sikerült a kívánt irányba terelni, hiszen továbbra is a csirke cordon a legtöbbször választott fö fogás, melyet kedveltségben a mázas kacsamell, a vaslapon sült borjú bécsi és a marhapörkölt követ. Ez egyértelmúen jelzi, hogy az étterem vendégköre az új trendek ellenére inkább a klasszikus ételeket részesíti előnyben. Az étlap kínálata is ellentmondásos, mert bár megjelennek az étlapon drágább, különleges ételek, de mellette ott van a csirke cordon és a marhapörkölt is. Az étlapon fóételként újonnan megjelent saláták kivétel nélkül az alacsony értékesítési volumenű ételek közé kerültek. 


\section{3. ábra: A fóételek értékesítési volumenének és árrésének ábrázolása \\ Kasavana - Smith mátrixban (2019)}

Figure 3. Representation of sales volume and margins of main courses

in the Kasavana - Smith matrix (2019)

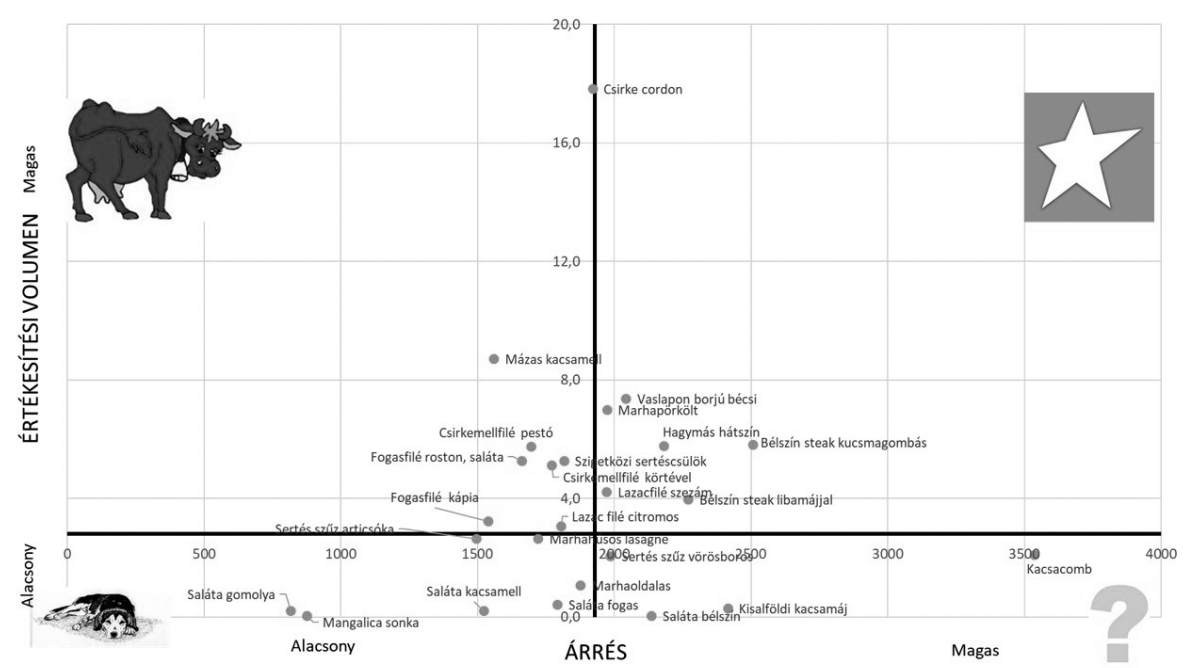

Megjegyzés: A mátrixban használt szimbólumok forrása: http://mediapedia.hu/bcg-matrix Forrás: saját szerkesztés

Az egyes évek elemzése, összehasonlítása után megvizsgáltuk azt is, hogy tetten érhetö-e a kínálat és a kereslet vonatkozásában szezonalitás.

A kínálat tekintetében a 2019 tavaszi és nyári étlapot vizsgáltuk. Az eltérést pusztán a saláták nyári megjelenése okozta, azonban mint az az általános elemzésből már kiderült, csekély érdeklődés jelentkezett ezen ételek iránt. Miután fogyasztói megkérdezés nem történt, így az okokra megbízható kijelentések nem tehetők, azonban az árak vizsgálata valószínüsíti, hogy az ár-értékarány nagyban befolyásolhatta a döntéseket, hiszen a saláták árai erősen közelítettek a körettel kínált hasonló hús alapanyaggal készült ételek áraihoz. A modell korlátaiból következik, hogy olyan választék nincs, amelyben csak „sztárok” vannak és nincsenek „döglött kutyák”, de megítélésünk szerint vezetői döntés, hogy a folyamatosan a „döglött kutyák” mezőben szereplő ételeket más ételekkel kell helyettesíteni. A „kérdőjelek” között szereplö ételek esetén is be kell avatkozni és árcsökkentéssel, vagy erősebb marketing tevékenységgel (ajánlás, akció) segíteni kell, hogy a vendégek megismerjék, megtalálják ezeket. Vannak nagyon népszerủ ételek, melyek elvonják a figyelmet más kínálati elemekröl. Kérdés, hogy ebben az esetben a többi ételt kell-e ezekhez igazítani vagy fordítva. 


\section{4. táblázat: Egyes ételek árai a 2019-ben}

Table 4. Prices of foods in 2019

\begin{tabular}{|l|l|}
\hline Ételek megnevezése & Ár (Ft) \\
\hline Gomolya saláta & 1590 \\
\hline Rozéra sült kacsamell színes saláta ágyon & 2490 \\
\hline Csirkemellfilé pestóval, aszalt paradicsommal sütve, tészta köret & 2590 \\
\hline Marhahúsos lasagne mozzarellával & 2590 \\
\hline Mázas kacsamell tonkababos almapürével és burgonyafánkkal & 2590 \\
\hline Sertésszüz articsókával vörösboros-fokhagymás aszaltszilvával és jázminrizzsel & 2590 \\
\hline Csirke cordon bleu vörös cheddarral pirított kockaburgonya & 2690 \\
\hline Marhapörkölt lábszárból házi galuska & 2690 \\
\hline „Szigetközi” mustáros sertéscsülök pirított burgonya & 2790 \\
\hline Fogasfilé zöld salátával és balzsamecettel & 2890 \\
\hline Fogasfilé roston marinált kápiával, limeos-chilis joghurttal, vadrizs & 2990 \\
\hline Vaslapon, vajon sült borjú bécsi, parázsburgonyával & 3490 \\
\hline Érlelt Black Angus hátszín dijoni mustárral, sült hagymával, héjas roppanós burgonyával & 3690 \\
\hline Hideg bélszínérmék kerti salátával tálalva & 3690 \\
\hline Lazacfilé pirított szezámmal, lencse, parajos vastag tészta & 3790 \\
\hline Bélszínsteak kucsmagombával, röszti & 4690 \\
\hline Bélszínsteak libamájjal madeira mártással, pirított zöldségekkel & 4790 \\
\hline
\end{tabular}

Forrás: saját szerkesztés az étteremtől kapott adatok alapján

Kutatásunkban a szezonalitást külön vizsgáltuk, de mint azt a 2019-es adatok alapján szerkesztett 4. ábránk bizonyítja, nem lehetett összefüggést találni az ételválasztás és a szezonalitás között. Ebben a vizsgált étterem esetén az is szerepet játszhatott, hogy az étlapon nem kaptak helyett klasszikusan egyes évszakokhoz szorosan kapcsolódó alapanyagokból készült ételek. 


\section{4. ábra: Az ételek vizsgálata a szezonalitás faktor bevonásával}

Figure 4. Examination of foods including the seasonality factor

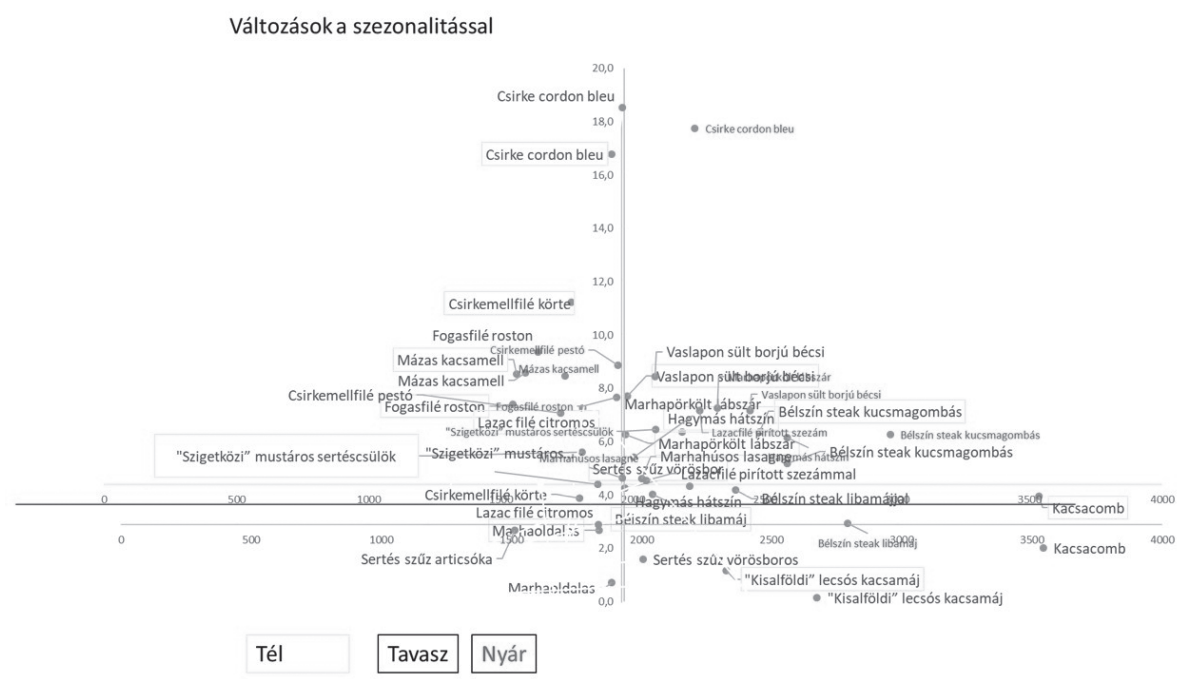

Megjegyzés: A mátrixban használt szimbólumok forrása: http://mediapedia.hu/bcg-matrix

Forrás: saját szerkesztés

Végül regresszióanalízissel vizsgáltuk az ár és az értékesítési volumen összefüggését. A vizsgálat során az Rértékének 0,359-t kaptunk ( $\mathrm{p}=0,018)$, ami azt jelenti, hogy az ár az ételválasztást 36\%ban magyarázta, így érdemes még nagyobb figyelmet fordítani az árazásra.

\section{KÖVETKEZTETÉSEK FINDINGS}

Kijelenthető, hogy a jól megtervezett, megfelelő áruválaszték felbecsülhetetlen az étterem üzemeltetői számára, mert képes meghatározni az étterem sikerét a versenyhelyzetben.

A jelenlegi tanulmányban alkalmazott modellnek vannak ugyan korlátai, de összességében jól bemutatta a vizsgált étterem választékának sajátosságait, a változtatások hatását a forgalmi adatokra.

$\mathrm{Az}$ étterem általános elemzésekor megállapítottuk, hogy az étterem próbál lépést tartani a vendéglátás új trendjeivel, azonban az elemzés is alátámasztotta, hogy mennyire fontos a megfelelő célcsoportok megtalálása és számukra célzott marketingtevékenység folytatása. A választék jelenlegi összetétele, szélessége és mélysége megítélésünk szerint nincs összhangban az étterem elhelyezkedésével, kialakításával, az elsődleges funkciójával (rendezvényszervezés). A haszonkulcs 4 év alatt a 120\%-ról 180\%-ra nőtt, mindeközben a forgalom lefeleződött az eladott adagok tekintetében és bár a bruttó bevétel stagnál, de közben az ÁFA 27 \%-ról 5 \%-ra mérséklődött. Az ár és az ételek értékesítése között vizsgálatunk alapján szignifikáns kapcsolat van, melyet az ár 36\%-ban magyarázza.

A szezonalitás vizsgálatra elsőként alkalmaztuk a Kasavana-Smith mátrixot. A vizsgálat eredményeként megállapítható, egyrészt, hogy a szezonalitás az étlapon csak csekély mértékben jelenik meg a választékban, de az értékesítés még ezt sem támasztja alá. A fogyasztók nem a szezonjellegü ételeket keresték elsősorban, hanem az ár-érték arányban legkedvezőbbnek tünőt. Összességében kijelenthető, hogy az étteremnek a fenti elemzés alapján érdemes újrapozícionálni magát és a célcsoportokat újradefiniálni.

\section{JAVASLATOK RECOMMENDATIONS}

Szükséges lenne a kínálatot jobban a célcsoporthoz igazítani. A rendezvények részére fenntartott populárisabb étterem mellett egy kisebb fine dining étterem kialakítása lehetséges a jelenlegi étterem 
megosztásával. Ha a jelenlegi célcsoport megtartása mellett dönt a menedzsment, akkor az árakat a célcsoporthoz kell igazítani, amivel növelhető a forgalom. Szükségszerű a marketingkommunikáció erősítése, a valós célcsoport megszólítása.

Ha csak a modellhez rendelt klasszikus intézkedéseket irányozzuk elő, akkor a „sztárok” mezőben szereplő ételek esetén- mivel ezek népszerüsége kiemelkedő, árrésük magas-, törekedni kell a magas minőségben való előállításra és arra, hogy a felszolgáló személyzet megfelelően ajánlja ezeket.

A „kérdőjelek” esetén, mivel ezek magas árréstartalommal bírnak, de kevésbé népszerúek, a megismertetésükre és ajánlásukra kell nagyobb hangsúlyt fektetni. Meg kell vizsgálni azt is, hogy némi árcsökkentés esetén változik-e az értékesítési volumen.

A ,fejőstehenek” esetén az étel nagy népszerüségnek örvend, de alacsony az árréstartalma, tehát meg kell próbálni kis áremeléssel a profitot növelni, vagy előnyösebb tálalással, némiképp csökkentve az adagot, az eredeti árat is megtartva biztosítható a magasabb árréstartalom.

A „döglött kutyák” mezőbe tartozó ételeket pedig próbáljuk lecserélni más ételekre. Némely esetben lehetséges, hogy sikert érhet el az étterem ugyanazon alapanyagból készített populárisabb étellel, de egyes esetekben pl. halaknál egyértelmüen látszott, hogy csak bizonyos halfajokat kedveltek/választottak a vendégeknek. A saláták esetén érdekes volt, hogy többségében alacsony árréstartalom volt a relatív magas ár mellett, melyet a fogyasztók a vizsgálat eredménye alapján nem fogadtak el.

Jelen kutatást a jövőben célszerü lenne kiegészíteni egy, a fogyasztói magatartást jobban feltáró kérdőíves megkérdezéssel.

\section{HIVATKOZÁSOK REFERENCES}

Bayou, M. E. and Bennett, L. B. (1992), "Profitability analysis for table-service restaurants", The Cornell Hotel and Restaurant Administration Quarterly, 33(2), 49-55, DOI: 10.1016/0010-8804(92)90082-G Borda J., Sándor L., Szabó E., Szigeti A. (1993), Gasztronómiai Lexikon, Budapest: Mezőgazda Kiadó

Cohen, E., Mesika, R. and Schwartz, Z. (1998), “A multidimensional approach to menu sales", Praxis, 2(1), 130-144

Dunszt K., Ónodi F., Oriskó F., Török I. J. (2005), Vendéglátó technológia, Budapest: Képzőmüvészeti Kiadó

Hayes, D. K. and Huffman, L. (1985), "Menu Analysis: A better way", Cornell Hotel and Restaurant Administration Quarterly, 26(3), 64-70, DOI: $10.1177 \% 2 \mathrm{~F} 001088048502500412$

Horton, B. W. (2001), Labor and menu category: Effects on analysis, FIU Hospitality and Tourism Review, 19(2), 35-46

Ivancsóné Horváth Zs., Kömíves Cs. (2018), A Rábaköz és a Szigetköz gasztronómiai gyökerei, In: Kupi M. -Printz-Markó E. - Ivancsóné Horváth Zs. (szerk.), «Út» a XXI. században. IX. Nemzetközi Konferencia, Széchenyi István Egyetem Kautz Gyula Gazdaságtudományi Kar, 239-250. Győr

Kasavana, M. L. and Smith, D. I. (1982), Menu engineering: A practical guide to menu analysis (1st ed.), Okemos, MI: Hospitality Publications

Kőmíves, Cs. (2018), Culinary heritage in Győr and its surrounding area, In: A-M. Lebrun (ed.) Proceedings 4th International Conference EATSA: Challenges of tourism development in Asia \& Europe Dijon, Franciaország: EATSA 56-64, DOI: 10.20319/pijss.2017.32.234245

LeBruto, S. M., Ashley, R. A. and Quain, W. (1995), "Menu engineering: a model including labor", FIU Hospitality Review, 13(1), 41-50

Miller, J. (1980), Menu pricing and strategy, Boston, MA: CBI Books

Pavesic, D. (1983), "Cost-Margin analysis: A third approach to menu pricing and design", International Journal of Hospitality Management, 2(3), 127-134, DOI: 10.1016/0278-4319(83)90033-6

Sándor D. (2007), “Tájjellegü ételek megjelenésének elemzése a dél-dunántúli turisztikai régió ételválasztékában", Budapesti Gazdasági Föiskola-Magyar Tudomány Napja, 194-208. Budapest

Taylor J. J. and Brown, D. M. (2007). "Menu Analysis: A Review of Techniques and Approaches", Hospitality Rewiew, 25(2/6)

Voleszák, Z. (2006), Pincér ismeretek, Sopron: POKJO61

4/2009. (I. 30.) NFGM-SZMM együttes rendelet a termékek eladási ára és egységára, továbbá a szolgáltatások díja feltüntetésének részletes szabályairól. https://net.jogtar.hu/jogszabaly?docid=a0900004. nfg (Letöltés ideje: 2019.11.30.)

1997. évi CLV. törvény a fogyasztóvédelemröl. https://net.jogtar.hu/jogszabaly?docid=99700155.tv. (Letöltés ideje: 2019.11.30.)

http://mediapedia.hu/bcg-matrix 
Ivancsóné Horváth Zsuzsanna, egyetemi docens ivancso.zsuzsa@sze.hu

Kömíves Csaba, tanársegéd komives.csaba@sze.hu

Nagy-Keglovich Júlia, tanársegéd nagy-keglovich.julia@sze.hu

Happ Éva, tanszékvezető egyetemi docens happ.eva@sze.hu

Széchenyi István Egyetem

\section{A feast for the eyes! Examining a menu in a Transdanubian restaurant on the basis of the Kasavana - Smith model}

\section{THE AIM OF THE PAPER}

Gastronomy is currently undergoing a renaissance, different gastronomic trends influence the way menus are set up. The purpose of this study is to investigate the menu of a restaurant in a Transdanubian city in terms of sold portions and margins.

\section{METHODOLOGY}

After an unstructured interview with the manager, the breadth and depth of the offer were investigated. Then the data were examined, based on the restaurant's menu selection, traffic and cost data with the help of time series analysis. During the processing of time series data, the analysis takes into account seasonality and compares the same terminology of the years studied. With the turnover and cost data, the Kasanava and Smith portfolio analysis method was used and based on the margin and the number of portions sold, the Menu engineering worksheet was used to create the data series for the presentation.

\section{MOST IMPORTANT RESULTS}

The research provides a detailed picture of sales decisions for the period 2016-2019. The results of the examination show that reducing the selection and offering special dishes are in line with the gastronomical trends, but not necessarily with the location of the restaurant and the needs of its target audience. Using the model, seasonality was examined for the first time, which did not prove that restaurant guests were looking for seasonal food.

\section{PRACTICAL IMPLICATIONS}

With a well-selected menu - which is one of the most important marketing communication tools - the restaurant is able to influence guests' food choices. Proper use of colours, shapes and prices all affect the guest's subconscious mind, which is responsible for a large percentage of decisions. The character of the restaurant and its guests are usually determined by the dishes on the menu. In the case of the investigated restaurant the solution could be to tailor the prices to the target group and to strengthen the marketing communication. The restaurant - taking advantage of the large space - can be used to serve different target groups by sharing the room.

Keywords: menu, Kasavana-Smith, matrix 